Огляди літератури, оригінальні дослідження, погляд на проблему, випадок з практики, короткі повідомлення УДК 615.451.16:582.28-06:616.36-002-099:615.212]-092.9

DOI 10.11603/1811-2471.2021.v.i3.12517

\title{
АКТИВНІСТЬ ЗАПАЛЬНИХ ПРОЦЕСІВ У ЩУРІВ ІЗ ТОКСИЧНИМ ПАРАЦЕТАМОЛОВИМ ГЕПАТИТОМ ТА ПІСЛЯ ЗАСТОСУВАННЯ СУХОГО ЕКСТРАКТУ $З$ ГРИБІВ РЕЙШИ
}

\section{ФІ. І. Герасимець, Л. С. Фіра, І. І. Медвідь, Р. І. Цицюра \\ Тернопільський начіональний медичний університет імені І. Я. Горбачевського МОЗ України}

PEЗЮМЕ. Зважаючи на те, що гострий гепатит може призвести до тяжких наслідків, існує необхідність максимально ранньої його діагностики та застосування ефективних гепатопротекторів для лікування та запобігання ускладненням.

Мета - дослідити протизапальні властивості сухого екстракту з грибів рейши в експерименті на щурах із токсичним гепатитом.

Матеріал і методи. Експеримент виконано на 60 білих щурах-самцях, рандомізованих на 10 груп по 6 тварин у кожній. Гострий гепатит моделювали шляхом введення парацетамолу (ацетамінофену) інтрагастрально у дозі 1250 мг/кг 1 раз на добу у вигляді суспензії в 2 \% розчині крохмального гелю протягом 2 діб. Для корекції токсичного ураження вводили сухий екстракт грибів рейши інтрагастрально за 2 години до введення ацетамінофену та щоденно після ураження в дозі 100 мг/кг маси тіла тварини. Як препарат порівняння було обрано Силібор (виробник - ТОВ «Фармацевтична компанія «Здоров'я»), який вводили за тією ж схемою, що й екстракт рейши, в дозі 20 мг/кг маси тіла щура. Евтаназію здійснювали на 3-тю, 7-му та 10-ту добу від початку ураження. Для досліджень брали гомогенат печінки та сироватку крові. Динаміку запальних процесів вивчали за вмістом про-, протизапальних цитокінів, С-реактивного протеїну у сироватці крові тварин із парацетамоловим гепатитом, а також після коригуючого впливу екстракту з грибів рейши та препарату порівняння.

Результати. Вивчено вміст прозапальних, протизапальних цитокінів та С-реактивного протеїну у сироватці крові щурів за умов парацетамолового гепатиту. Встановлено, що сухий екстракт грибів рейши достовірно зменшує рівень прозапального IL-6 та C-реактивного протеїну, підвищує рівень протизапального IL-4 в сироватці крові щурів за умов токсичного ураження.

Висновки. Отримані результати свідчать про пригнічення запальних процесів під впливом сухого екстракту з грибів рейши за умов парацетамолового гепатиту у щурів. Протизапальні властивості досліджуваного екстракту $\epsilon$ одним із механізмів його стресадаптогенної та гепатопротекторної дії.

КЛючОВІ СлОВА: гриби рейши; парацетамол; гепатит; запальні процеси; сухий екстракт; протизапальні властивості.

Вступ. Печінка відіграє основну роль у метаболізмі, біотрансформації більшості речовин, які надходять в організм із зовнішнього середовища, зокрема й медикаментів. Наразі відомо понад 300 медикаментозних препаратів, які здатні викликати пошкодження печінки.

Одним із популярних медикаментозних засобів в Україні й світі $\epsilon$ парацетамол (ацетамінофен), який рутинно вважають найбезпечнішим з великої групи засобів, що мають анальгетичну/антипіретичну дію $[1,2]$. Відомо також, що передозування, а також застосування його на фоні провокуючих чинників (гострі й хронічні ураження печінки, низький вміст білка в раціоні, алкоголізм) може викликати некротичні зміни в клітинах печінки з наступним розвитком печінкової недостатності.

У багатьох лабораторіях вивчають роль макрофагальних клітин в токсичності парацетамолу $[3,4]$. У печінці макрофагальними клітинами $\epsilon$ клітини Купфера. Відомо, що в процесі життєдіяльності зазначених клітин продукується ряд біологічно активних молекул, серед яких $\epsilon$ гідролітичні ферменти, ейкозаноїди, нітрогену оксид, супероксид. Крім них, у контакті з парацетамолом, куп- ферівські клітини здатні вивільняти деякі прозапальні цитокіни, що призводить до розвитку запалення в організмі.

Для лікування токсичних та медикаментозних гепатитів широко використовують препарати рослинного та синтетичного походження $[4,5]$.

Важливими особливостями фітопрепаратів $\epsilon$ широкий діапазон терапевтичних доз, здатність активно впливати на уражені мембранно-клітинні структури та метаболічні процеси, висока біодоступність, м'яка дія на організм та фізіологічна корекція порушених функцій, низькі токсичність та алергенність, i, у багатьох випадках, - ціна [5, 6]. Враховуючи вищезазначене, як перспективну сировину було вибрано гриби рейши.

Гриби рейши дуже високо цінуються за свої лікувальні властивості. Східна медицина застосовує рейши при будь-яких захворюваннях, зокрема при захворюваннях печінки. Для кожної хвороби існує свій спосіб приготування та дозування грибів. Японські вчені доводять, що рейши допомагає боротися з передчасним старінням, особливо сприятливо впливає на шкіру і печінку; сприяє посиленню імунітету та пригніченню розвитку пухлин різного походження; позитивно впливає на нервову 
Огляди літератури, оригінальні дослідження, погляд на проблему, випадок з практики, короткі повідомлення систему, оскільки активізує вироблення в організмі «гормону щастя»; допомагає боротися з ожирінням та нормалізує рівень цукру в крові; сприяє покращенню показників крові, зокрема насиченості ії киснем; допомагає нормалізувати тиск; знизити рівень холестерину; перешкоджає утворенню тромбів; сприяє мобілізації ресурсів організму, що $\epsilon$ важливим під час сильних фізичних і психологічних навантажень, а також в період сезонних епідемій $[7,8]$.

Мета - вивчити протизапальні властивості сухого екстракту з грибів рейши в експерименті на щурах із гострим гепатитом, індукованим парацетамолом (ацетамінофеном).

Матеріал і методи дослідження. Матеріалом для проведення експериментальної роботи слугував сухий екстракт з грибів рейши (СЕГР), одержаний науковцями кафедри хімії природних сполук Національного фармацевтичного університету.

Досліди проводили на білих безпородних щурах-самцях, масою 180-210 г, що утримувались на стандартному раціоні віварію Тернопільського національного медичного університету імені І. Я. Горбачевського. Усі дослідження проводили з дотриманням правил біоетики відповідно до «Європейської конвенції про захист хребетних тварин, які використовуються для експериментальних та інших наукових цілей» [9].

Моделлю токсичного ураження щурів слугувала інтоксикація ацетамінофеном, який вводили інтрагастрально у дозі 1250 мг/кг 1 раз на добу протягом 2 діб у вигляді суспензії в $2 \%$ розчині крохмального гелю. СЕГР вводили інтрагастрально за 2 години до введення токсичного агента та щоденно після ураження в дозі 100 мг/кг маси тіла тварини, яка попередніми нашими дослідженнями була встановлена як умовно терапевтична для даного екстракту [10]. Препаратом порівняння обрали Силібор (діючою основою є силімарин), який вводили за тією ж схемою, що i досліджуваний екстракт, в дозі 20 мг/кг маси тіла тварини. Значення дози препарату порівняння було обрано виходячи з інструкції щодо його застосування та з використанням коефіцієнтів видової чутливості Риболовлєва Ю. Р. та його методу перерахунку дози для людини на дозу для щура $[5,11]$. Тварини були рандомізовані на 10 груп, по 6 щурів кожна: 1-ша - тварини інтактного контролю; 2-га, 3-тя та 4-та - тварини, отруєні ацетамінофеном, 3-тя , 7-ма та 10-та доби дослідження відповідно; 5-та, 6-та та 7-ма групи - щури, яким вводили екстракт з грибів рейши в дозі 100 мг/кг маси тіла, 3-тя , 7-ма та 10-та доби експерименту відповідно; 8-ій, 9-ій та 10-ій групам тварин, яким інтрагастрально вводили препарат порівняння силібор, 3-тя, 7-ма та 10-та доби дослідження відповідно. Евтаназію проводили з використанням барбамілу натрію на 3-тю, 7-му та 10-ту добу експерименту. Дослідженням піддавали гомогенат печінки та сироватку крові. Кров забирали із серця тварин. Концентрацію про- та протизапальних інтерлейкінів у сироватці крові щурів визначали імуноферментним методом за допомогою комерційних наборів ("GE Health саге: Amersham", Велика Британія) [12, 13]. Вміст С-реактивного протеїну (СРП) визначали імунотурбідиметричним методом $[14,15]$.

Одержані дані статистично обробляли в програмі STATISTICA 12. Вірогідність міжгрупових відмінностей визначали за допомогою критерію рангових сум Вілкоксона та критерію Манна - Уїтні. Результати дослідження вважали вірогідними при р $\leq 0,05[16,17]$.

Результати й обговорення. Визначення вмісту С-реактивного протеїну $\epsilon$ високочутливим методом дослідження, що дозволяє виявити навіть незначне його зростання у сироватці крові. Таке незначне підвищення характерне для запальних процесів у стінках судин, атеросклерозу, підвищеного ризику розвитку захворювань печінки та серцево-судинної системи.

Особливістю С-реактивного протеїну $\epsilon$ те, що його синтез, який відбувається у печінці, починається лише під впливом факторів, які викликають запальний процес [18].

Ми встановили, що у щурів із гострим гепатитом, індукованим ацетамінофеном, у сироватці крові вміст СРП підвищився в 1,9, 2,4 та 2,7 раза на 3-тю, 7-му та 10-ту доби дослідження відповідно щодо групи інтактного контролю. Після корекції СЕГР спостерігалось вірогідне зниження вмісту СРП в сироватці крові щурів у 1,2, 1,7 та 2,4 раза на 3-тю, 7-му та 10-ту доби експерименту відповідно, порівняно з тваринами контрольної патології. При застосуванні силібору досліджуваний показник вірогідно $(p<0,05)$ знизився в 1,4 та 1,9 раза на 7-му та 10-ту доби експерименту відповідно, порівняно з тваринами із токсичним гепатитом (табл. 1).

Одержані результати дослідження підтверджують розвиток запальних процесів в організмі тварин при гострому токсичному гепатиті, який викликаний дією ацетамінофену.

Метод визначення СРП має високу чутливість, проте він $\epsilon$ неспецифічною ознакою запального процесу. Тобто, підтверджуючи наявність запалення, дане дослідження саме по собі не може вказати на уражений орган та допомогти встановити діагноз. Тому визначення вмісту СРП потрібно проводити в комплексі з визначенням інших показників. 
Огляди літератури, оригінальні дослідження, погляд на проблему, випадок з практики, короткі повідомлення

Таблиця 1. Вміст С-реактивного протеїну в сироватці крові (мг/л) щурів, уражених ацетамінофеном, та після застосування екстракту з грибів рейши $(\mathrm{M} \pm \mathrm{m} ; \mathrm{n}=60)$

\begin{tabular}{|l|c|c|c|}
\hline \multirow{2}{*}{ Групи тварин } & \multicolumn{3}{|c|}{ Термін експерименту } \\
\cline { 2 - 4 } & 3-тя до6а & $7-м а$ до6а & 10-та до6а \\
\hline IK & $3,51 \pm 0,28$ & $3,51 \pm 0,28$ & $9,51 \pm 0,28$ \\
\hline КП & $6,83 \pm 0,23^{*}$ & $8,47 \pm 0,24 *$ & $5,32^{*}$ \\
\hline КП+ силібор & $6,10 \pm 0,20$ & $5,93 \pm 0,29 * *$ & $3,97 \pm 0,23^{* *}$ \\
\hline КП+СЕГР & $5,56 \pm 0,25^{* *}$ & $5,07 \pm 0,31^{* *}$ & \\
\hline
\end{tabular}

Примітка. Тут і в наступних таблицях * - вірогідні зміни між показником контрольних та уражених парацетамолом тварин, ** - вірогідні зміни між показником уражених парацетамолом та лікованих тварин.

Наступним етапом нашого дослідження було визначення вмісту в сироватці крові щурів цитокінів - ендогенних гормоноподібних протеїнів, пептидів та медіаторів запалення, що продукуються активованими клітинами різних типів, зокрема, макрофагами та купферівськими клітинами печінки, у відповідь на позаклітинний зовнішній стимул, беруть участь у формуванні та регуляції захисних реакцій організму [19].

Ми вивчили вміст про- та протизапальних цитокінів, IL-4 та IL-6 у сироватці крові щурів із моде- льованим ацетамінофеновим гепатитом, а також дослідили коригуючий вплив на них СЕГР та силібору.

Експериментально встановлено, що за формування гострого гепатиту в щурів уже на 3-тю добу дослідження вміст IL-6 збільшився на 82 \%, порівняно з інтактними тваринами. На 7-му та 10-ту доби експерименту вміст досліджуваного показника зріс на $126 \%$ та 150 \% відповідно, порівняно з тваринами інтактного контролю (табл. 2).

Таблиця 2. Вміст IL-6 у сироватці крові (пг/л) щурів, уражених ацетамінофеном, та після застосування екстракту з грибів рейши $(M \pm m ; n=60)$

\begin{tabular}{|l|c|c|c|}
\hline \multirow{2}{*}{ Групи тварин } & \multicolumn{3}{|c|}{ Термін експерименту } \\
\cline { 2 - 4 } & 3-тя доба & 7-ма доба & 10-та доба \\
\hline IK & $2,96 \pm 0,22$ & $2,96 \pm 0,22$ & $2,96 \pm 0,22$ \\
\hline КП & $5,38 \pm 0,30^{*}$ & $6,69 \pm 0,34^{*}$ & $4,39 \pm 0,27^{*}$ \\
\hline КП+ силібор & $4,93 \pm 0,21$ & $4,51 \pm 0,26^{* *}$ & $3,60 \pm 0,29^{* *}$ \\
\hline КП+СЕГР & $4,66 \pm 0,18$ & $3,86 \pm 0,28^{* *}$ \\
\hline
\end{tabular}

Застосування СЕГР з метою корекції виявлених порушень за токсичного гепатиту привело до вірогідного зниження вмісту IL-6 вже на 7-му добу дослідження відносно контролю. Препарат порівняння Силібор також проявив позитивний вплив на цей показник.

Вміст протизапального IL-4 може вказувати на ризик виникнення ускладнень при запальному процесі, адже його зниження у сироватці крові свідчить про виснаження протизапальних можливостей організму. Після ураження тварин ацетамінофеном у сироватці крові встановлено статистично вірогідне зменшення вмісту IL-4 в 1,4, 1,5 та 1,6 раза на 3-тю, 7-му та 10-ту доби експерименту відповідно щодо групи тварин інтактного контролю (табл. 3).

Таблиця 3. Вміст IL-4 у сироватці крові (пг/л) щурів, уражених ацетамінофеном, та після застосування екстракту з грибів рейши $(M \pm m ; n=60)$

\begin{tabular}{|l|c|c|c|}
\hline \multirow{2}{*}{ Групи тварин } & \multicolumn{3}{|c|}{ Термін експерименту } \\
\cline { 2 - 4 } & 3-тя доба & 7 -ма доба & 10 -та доба \\
\hline IK & $1,57 \pm 0,08$ & $1,57 \pm 0,08$ & $0,57 \pm 0,08$ \\
\hline КП & $1,14 \pm 0,05^{*}$ & $1,03 \pm 0,07^{*}$ & $1,34 \pm 0,06^{* *}$ \\
\hline КП+ силібор & $1,22 \pm 0,07$ & $1,29 \pm 0,08^{* *}$ & $1,52 \pm 0,11^{* *}$ \\
\hline КП+СЕГР & $1,34 \pm 0,08$ & $1,47 \pm 0,07^{* *}$ & \\
\hline
\end{tabular}

Застосування СЕГР призвело до вірогідного підвищення вмісту IL-4 на $43 \%$ та 58 \% на 7-му та 10-ту доби дослідження відповідно, порівняно 3 тваринами із токсичним гепатитом. При застосуван- ні препарату порівняння відмічали вірогідне $(p<0,05)$ підвищення вмісту даного цитокіну на 7-му добу в 1,3 раза та в 1,4 раза на 10-ту добу дослідження, порівняно з групою контрольної патології. 
Огляди літератури, оригінальні дослідження, погляд на проблему, випадок з практики, короткі повідомлення

Одержані результати дозволяють припустити, що застосування СЕГР щурам в дозі 100 мг/кг протягом 10 діб позитивно впливає на початкові етапи формування запальної реакції.

Висновки. Встановлено, що за умов гострого гепатиту у щурів, індукованого введенням ацетамінофену, у сироватці крові зросла концентрація СРП, вірогідно підвищився вміст прозапального ІЛ-6 та знизився вміст протизапального цитокіну IL-4, що свідчить про розвиток запальних процесів в уражених тварин.

Нами підтверджена імунокоригуюча дія досліджуваного екстракту, яка полягає в зміні цитокінового профілю, зокрема у зниженні в динаміці вмісту прозапального ІЛ-6 та підвищення вмісту протизапального цитокіну ІЛ-4 відносно групи щурів з токсичним гепатитом.

Застосування СЕГР позитивно вплинуло на вміст СРП та цитокінів у сироватці крові тварин 3 гострим гепатитом, що вказує на його протизапальні, цитопротекторні властивості та доцільність подальшого вивчення з метою створення ефективних лікарських засобів.

Перспективи подальших досліджень полягають у більш глибокому вивченні сухого екстракту грибів рейши як ефективного протизапального та цитопротекторного лікарського засобу, який зміг би використовуватись для профілактики та лікування патологічних станів, що супроводжуються розвитком запальних процесів в організмі.

\section{ЛІТЕРАТУРА}

1. Волошина Н. Б. Фульминантный парацетамолоВый гепатит / Н. Б. Волошина, М. Ф. Осипенко, Н. В. Литвинова // Экспериментальная и клиническая гастроэнтерология. - 2016. - № 9. - С. 103-106.

2. Калько К. О. Циркадіанна залежність гепатопротекторної активності антралю на моделі гострого парацетамолового гепатиту у щурів / К. О. Калько, С. М. Дроговоз // Фармакологія та лікарська токсикологія. 2017. - № 2 (54). - С. 62-68.

3. Клекот О. О. Безпека застосування парацетамолу в клінічній практиці / О. О. Клекот, О. О. Яковлева // Pain Medicine Journal. - 2016. - № 3 (3). - C. 41-48.

4. Хронофармакологические особенности действия гепатопротекторов в эксперименте / Н. Д. Бунятян, Е. А. Калько, С. М. Дроговоз [и др.] // Бюл. експеримент. биологии и медицины. - 2018. - № 6. - С. 712-715. DOI: https://doi.org/10.1007/s10517-018-4258-8

5. Герасимець І. І. Вивчення гепатопротекторних властивостей сухого екстракту грибів рейши / І. І. Герасимець, Л. С. Фіра, І. І. Медвідь // Український біофармацевтичний журнал. - 2019. - № 4 (61). - С. 28-34. DOI: https://doi.org/10.24959/ubphj.19.232.

6. Гриби як перспективна сировина для застосування в медицині / В. С. Кисличенко, Т. П. Гарник, І. О. Журавель [та ін.] // Фітотерапія. Часопис. - 2013. № 1. - С. 31-35.

7. Veljovićetal S. Chemical composition, antiproliferative andantioxidant activity of differently processed Ganoderma lucidum ethanol extracts / S. Veljovićetal // Journal of food science and technology. - 2017. - Vol. 54, Iss. 5. - P. 1312-1320. DOI: https://doi.org/10.1007/ s13197-017-2559-y.

8. Zengetal P. Chemical, biochemical, preclinical and clinical studies of Ganoderma lucidum polysaccharide as anapproved drug for treating myopathy and other diseases in China / P. Zengetal // Journal of cellular and molecular medicine. - 2018. - Vol. 22, Iss. 7. - P. 3278-3297. DOI: https://doi.org/10.1111/jcmm.13613.

9. Gross D. Ethics in Animal-Based Research / D. Gross, R. Tolba // Eur. Surg. Res. - 2015. - Vol. 55, No. 1-2. - P. 43-57. DOI: https://doi.org/10.1159/000377721.

10. Герасимець І. І. Встановлення умовно терапевтичної дози сухого екстракту з грибів рейши на моделі токсичного гепатиту / І. І. Герасимець, Л. С. Фіра, І. І. Медвідь // Danish Scientific Journal. - Kobenhavn, Danmark. - 2020. - № 38. - C. 12-16.

11. Рыболовлев Ю. Р. Дозирование веществ для млекопитающих по константам биологической активности / Ю. Р. Рыболовлев, Р. С. Рыболовлев // Доклады AH CCCP. - 1979. - T. 247, № 6. - C. 1513-1516.

12. Cigarette smoke-induced cerebral cortical interleukin-6 elevation is not mediated through oxidative stress / W. K. Lau, J. C. Mak, K. H. Chan [et al.] // Neurotoxicity Research. - 2012. - Vol. 22(2) . - P. 170-176.

13. Altynbaeva Y. I. Cell damage markers, cytokines and terminal stable metabolites of nitric oxide in saliva in smoking patients in the early stages of chronic obstructive pulmonary disease / Y. I. Altynbaeva, S. N. Teplova // Cytokines and inflammation. - 2011. - Vol. 4. - P. 15-22.

14. Analysis of the quantitative determination of the level of C-reactive protein and procalcitonin in patients with infectious diseases / K. M. Alybaeva, N. A. Berdyyarova, N. K. Mukhamedzhanova [et al.] // Bulletin of AGIUV. 2015. - Vol. 1-2. - P. 36-40. DOI: https://doi.org/10.5546/ aap.2015.36.

15. C-reactive protein, interleukin- 6 and the risk of colorectal cancer: a meta-analysis / B. Zhou, B. Shu, J. Yang [et al.] // Cancer Causes Control. - 2014. - Vol. 25(10). - P. 13971405. DOI: https://doi.org/10.1007/s10552-014-0445-8.

16. Шеламова М. А. Статистический анализ медико-биологических данных с использованием программы EXCEL / М. А. Шеламова, Н. И. Инсарова, В. Г. Лещенко. - Минск : БГМУ, 2010. - 96 с.

17. Citation bias favoring statistically significant studies was present in medical research / A. S. Jannot, T. Agoritsas, A. Gayet-Ageron [et al.] // J. Clin. Epidemiol. - 2013.No. 66(3). - P. 296-301. DOI: https://doi.org/10.1016/j. jclinepi.2012.09.015.

18. Associations of circulating C-reactive protein and interleukin- 6 with cancer risk: findings from two prospective cohorts and a meta-analysis / K. Heikkilä, R. Harris, G. Lowe [et al.] // Cancer Causes Control. - 2009. - Vol. 20. - P. 15-26. 
Огляди літератури, оригінальні дослідження, погляд на проблему, випадок з практики, короткі повідомлення DOI: https://doi.org/10.1007/s10552-008-9212-z. [PubMed].

19. Interleukin-13/-4-induced oxidative stress contributes to death of hippocampal neurons in a 1 1-42-

treated hippocampus in vivo / J. Nam, K. Park, E. Park [et al.] // Antioxid. Redox. Signal. - 2012 Jun. - 16(12). P.1369-1383.DOI: https://doi.org/10.1089/ars.2011.4175.

\section{REFERENCES}

1. Voloshyna, N.B., Osypenko, M.F., \& Lytvynova, N.V. (2016). Fulminantnyi paratsetamolovyi gepatyt [Fulminant paracetamol hepatitis]. Eksperimentalnaya i klinicheskaya gastroenterologiya - Eksperimental and Clinical Hastroenterology, 9, 103-106 [in Russian].

2. Kalko, K.O., \& Drohovoz, S.M. (2017). Tsyrkadianna zalezhnist hepatoprotektornoi aktyvnosti antralyu na modeli hostroho paratsetamolovoho hepatytu u shchuriv [Circadian dependence of antral hepatoprotective activity in a model of acute paracetamol hepatitis in rats]. Farmakolohiya ta likarska toksykolohiya - Pharmacology and Drug Toxicology, 2 (54), 62-68 [in Ukrainian].

3. Klekot, O.O., \& Yakovleva, O.O. (2016). Bezpeka zastosuvannia paratsetamolu v klinichnii praktytsi [Safety of paracetamol use in clinical practice]. Pain Medicine Journal, 3 (3), 41-48 [in Ukrainian].

4. Bunyatyan, N.D., Kalko, E.A., \& Drogovoz, S.M. (2018). Hronofarmakologicheskie osobennosti dejstviya gepatoprotektorov $v$ eksperimente [Chronopharmacological features of the action of hepatoprotectors in the experiment]. Biul. eksperiment. biologii i mediciny- Bul. Experiment. Biology and Medicine, 6, 712-715. DOI: https:// doi.org/10.1007/s10517-018-4258-8 [in Russian].

5. Herasymets, I.I., Fira, L.S., \& Medvid, I.I. (2019). Vyznachennia hepatoprotektornykh vlastyvostei sukhoho ekstraktu hrybiv reishy [Determination of hepatoprotective properties of dry reishi mushroom extract]. Ukrainskyi biofarmatsevtychnyi zhurnal - Ukrainian Biopharmaceutical Journal, 4, 28-34. DOI: https://doi.org/10.24959/ubphj.19.232. [in Ukrainian].

6. Kyslichenko, V.S, Harnyk, T.P., \& Zhuravel I.O. (2013). Hryby yak perspektyvna syrovyna dlya zastosuvannia v medytsyni [Mushrooms as a promising raw material for use in medicine]. Fitoterapiya. Chasopys - Phitotherapy. Magazine, 1, 31-35. [in Ukrainian].

7. Veljovićetal, S. (2017). Chemical composition, antiproliferative andantioxidant activity of differently processed Ganoderma lucidum ethanol extracts. Journal of Food Science and Technology, 54, (5), 1312-1320. DOI: https://doi.org/10.1007/s13197-017-2559-y.

8. Zengetal, P. (2018). Chemical, biochemical, preclinical and clinical studies of Ganoderma lucidum polysaccharide as anapproved drug for treating myopathy and other diseases in China. Journal of Cellular and Molecular Medicine, 22, (7), 3278-3297. DOI: https://doi.org/10.1111/ jcmm.13613.

9. Gross, D, \& Tolba, R. (2015). Ethics in AnimalBased Research. Eur. Surg. Res., 55(1-2), 43-57. https://doi. org/10.1159/000377721

10. Herasymets, I.I., Fira, L.S., \& Medvid I.I. (2020). Vstanovlennia umovno terapevtychnoi dozy sukhoho ekstraktu z hrybiv reishy na modeli toksychnoho hepatytu [Establishing a conditionally therapeutic dose of dry extract of Reishi mushrooms on a model of toxic hepatitis]. Danish Scientific Journal, 38, 12-16. [in Ukrainian].

11. Rybolovlev, Y.R., \& Rybolovlev, R.S. (1979). Dozirovanie veshchestv dlya mlekopitayushchikh po konstantam biologicheskoi aktivnosti [Dosing of substances for mammals according to the constants of biological activity]. Doklady AN SSSR - Reports of the USSR Academy of Sciences, 247 (6), 1513-1516 [ in Russian].

12. Lau, W.K., Mak, J.C., \& Chan, K.H. (2012). Cigarette smoke-induced cerebral cortical interleukin-6 elevation is not mediated through oxidative stress. Neurotoxicity $R e-$ search, 22(2), 170-176.

13. Altynbaeva, Y.I., \& Teplova, S.N. (2011). Cell damage markers, cytokines and terminal stable metabolites of nitric oxide in saliva in smoking patients in the early stages of chronic obstructive pulmonary disease. Cytokines and inflammation, 4, 15-22.

14. Alybaeva, K.M., Berdyyarova, N.A, \& Mukhamedzhanova, N.K. (2015). Analysis of the quantitative determination of the level of C-reactive protein and procalcitonin in patients with infectious diseases. Bulletin of AGIUV, 1-2, 36-40. DOI: https://doi.org/10.5546/aap.2015.36.

15. Zhou, B., Shu, B., \& Yang, J. (2014). C-reactive protein, interleukin- 6 and the risk of colorectal cancer: a meta-analysis. Cancer Causes Control, 25(10), 1397-1405. DOI: https://doi.org/10.1007/s10552-014-0445-8

16. Shelamova, M.A., Insarova, N.I., \& Lieshchienko, V.H. (2010). Statisticheskii analiz miediko-biologichieskikh dannykh s ispolzovaniiem programmy EXCEL [Statistical analysis of biomedical data using the EXCEL program]. Minsk: BGMU [in Russian].

17. Jannot, A.S., Agoritsas, T., \& Gayet-Ageron, A. (2013). Citation bias favoring statistically significant studies was present in medical research. J. Clin Epidemiol, 66(3), 296-301.DOI:https://doi.org/10.1016/j.jclinepi.2012.09.015

18. Heikkilä, K., Harris, R., Lowe, G. (2009). Associations of circulating C-reactive protein and interleukin-6 with cancer risk: findings from two prospective cohorts and a meta-analysis. Cancer Causes Control, 20, 15-26. DOI: https://doi.org/10.1007/s10552-008-9212-z.

19. Nam, J., Park, K., Park, E., Lee, Y.B., Lee, H.G., Baik, H.H. (2012). Interleukin-13/-4-induced oxidative stress contributes to death of hippocampal neurons in a $\beta 1-42-$ treated hippocampus in vivo. Antioxid. Redox. Signal, 16(12), 1369-1383. DOI: https://doi.org/10.1089/ars.2011.4175. 

AND AFTER APPLICATION OF DRY EXTRACT FROM REISHI MUSHROOMS

\section{Horbachevsky Ternopil National Medical University}

SUMMARY. Due to the fact that acute hepatitis can lead to serious consequences, there is a need for early diagnosis and the use of effective hepatoprotectors to treat and prevent complications.

The aim - to investigate the anti-inflammatory properties of dry Reishi mushroom extract in an experiment on rats with toxic hepatitis.

Material and Methods. The experiment was performed on 60 white male rats randomized to 10 groups of 6 animals each. Acute hepatitis was simulated by administration of paracetamol (acetaminophen) intragastrically at a dose of $1250 \mathrm{mg} / \mathrm{kg} 1$ time per day as a suspension in a $2 \%$ solution of starch gel for 2 days. Dry Reishi mushroom extract was administered intragastrally 2 hours before acetaminophen administration and daily after the lesion at a dose of $100 \mathrm{mg} / \mathrm{kg}$ of body weight to correct the toxic lesion. "Silibor" (manufacturer - LLC "Pharmaceutical Company" Health ") was chosen as a comparison drug and administered according to the same regimen as reishi extract at a dose of $20 \mathrm{mg} / \mathrm{kg}$ of rat body weight. Euthanasia was performed on the 3rd, 7th and 10th day from the onset of the lesion. Liver homogenate and blood serum were used for the studies. The dynamics of inflammatory processes was studied by the content of pro-, anti-inflammatory cytokines, C-reactive protein in the serum of animals with paracetamol hepatitis, as well as after the corrective effect of Reishi mushroom extract and the comparison drug.

Results. The content of pro-inflammatory, anti-inflammatory cytokines and C-reactive protein in the serum of rats under conditions of paracetamol hepatitis was studied. It was found that the dry extract of Reishi mushrooms significantly reduces the level of pro-inflammatory IL-6 and C-reactive protein, increases the level of anti-inflammatory IL-4 in the serum of rats under conditions of toxic lesions.

Conclusions. The obtained results indicate the suppression of inflammatory processes under the influence of dry extract of Reishi mushrooms under conditions of paracetamol hepatitis in rats. The anti-inflammatory properties of the studied extract are one of the mechanisms of its stress-adaptogenic and hepatoprotective action

KEY WORDS: Reishi mushrooms, paracetamol, hepatitis, inflammatory processes, dry extract, anti-inflammatory properties.

Отримано 28.09.2021 